\title{
COVID 19 AND THE MALAYSIAN ZOO PREVENTIVE MEASURE READINESS
}

\author{
DENNIS CHOON YUNG TEN ${ }^{1,2}$, HISHAM ATAN EDINUR ${ }^{3}$, ROHANA JANI ${ }^{4 *}$, NOOR \\ HASHIDA HASHIM ${ }^{5}$ AND MOHD TAJUDDIN ABDULLAH*6,7,8
}

\begin{abstract}
${ }^{1}$ Institute for Advanced Studies, University of Malaya, Jalan Universiti, 50603 Kuala Lumpur, Wilayah Persekutuan Kuala Lumpur, Malaysia. ${ }^{2}$ Department of Wildlife and National Parks, KM10, Jalan Cheras, 56100 Kuala Lumpur, Malaysia. ${ }^{3}$ Forensic Science Programme, School of Health Sciences, Universiti Sains Malaysia, Health Campus, 16150 Kubang Kerian, Kelantan, Malaysia. ${ }^{4}$ Faculty of Economics and Administration, University of Malaya, Jalan Universiti, 50603 Kuala Lumpur, Malaysia. ${ }^{5}$ Center for Foundation Studies in Science, University of Malaya, Jalan Universiti, 50603 Kuala Lumpur, Malaysia. ${ }^{6}$ Institute for Tropical Biodiversity and Sustainable Development, Universiti Malaysia Terengganu, 21030 Kuala Nerus, Terengganu, Malaysia. ${ }^{7}$ Faculty of Science and Marine Environment, University Malaysia Terengganu, 21030 Kuala Nerus, Terengganu, Malaysia. ${ }^{8}$ Fellow of Academy of Sciences Malaysia, Level 20, West Wing, Menara MATRADE, Jalan Sultan Haji Ahmad Shah, 50480 Kuala Lumpur, Malaysia.
\end{abstract}

*Corresponding author: abdullahmt@gmail.com

Submitted final draft: 1 December 2020 Accepted: 5 December 2020

http://doi.org/10.46754/jssm.2021.01.006

\begin{abstract}
The COVID-19 pandemic is due to SARS-CoV-2 and is spreading into 215 countries in the world. The COVID-19 is a zoonotic disease, and human to human transmission is possible via direct and indirect contact with infected individuals and contaminated surfaces. Recently, captive species of wild cats were tested positive for the COVID-19, and this is evidence of possible transmission of SARS-CoV-2 from human to animal, i.e., zooanthroponosis. In particular, the zoos should reduce the risk of introducing SARS-CoV-2 to the captive animals from the tourists or their workers. The risks can be reduced by implementing the preventive measure responses following the emergence of zoonotic disease. In this commentary article, we provide the existing disease control measures and have proposed several other preventive measures for the management of zooanthroponosis in various zoos located in Peninsular Malaysia.
\end{abstract}

Keywords: Post-COVID-19, zoonotic diseases, ex situ conservation, wildlife management policy, sustainability.

\section{Introduction}

The coronavirus disease (COVID-19) has now spread into 215 countries and territories in the world, with 28,637,952 and 917,417 confirmed cases and deaths, respectively (WHO, 2020). This pandemic is thus our major health, economic and humanitarian catastrophe that calls for a sustainable solution for months to come. The COVID-19 is thus a new pandemic caused by the Severe Acute Respiratory Syndrome Coronavirus-2 (SARS-CoV-2) (OIE, 2020). Currently, the evidence suggests that the SARS-CoV-2 emerged and was transmitted from animal to human (Daly, 2020; OIE, 2020). 70\% of emerging infectious diseases in humans are of zoonotic origin (Salyer et al., 2017). In the case of COVID-19, it is widely claimed that the SARS-CoV-2 originated from the bats (Ji et al., 2020; Zhou et al., 2020) and possibly contracted with a human via Malayan Pangolin (Lam et al., 2020; Liu et al., 2019).

Recently, the Malayan Tiger (Panthera tigris jacksoni) kept at the Bronx Zoo, the United States of America was tested positive for SARSCoV-2. This was the first reported zooanthroponosis case (i.e. transmission of disease from human to wildlife) due to direct exposure with COVID-19 infected worker (McGreevy, 2020). Later, three African Lions and four other captive Malayan Tigers at the same facility were tested positive for SARSCoV-2 (McGreevy, 2020; WCS, 2020). Another coronavirus (e.g., Severe Acute Respiratory Syndrome coronavirus: SARS CoV) also caused respiratory disease (SARS) outbreak (WHO, 2003) and was isolated from the Viverridae family including civets, genets and linsangs. However, there is no clear evidence to support 

transmission from human to animals (Guan et al., 2003).

The COVID-19 infected Malayan Tiger was not by chance, and research found that SARS-CoV-2 replicates efficiently in ferrets and cats (Shi et al., 2020). The four species of Malaysian otters are within the Mustelidae family as the ferrets (DWNP, 2017b). Another case of zooanthroponosis was recorded in 2009 where seven captive-bred chimpanzees in Chicago Zoo, the United States were infected by the keeper positive for human metapneumovirus (Owen et al., 2014). There are also reports that human metapneumovirus has infected wild chimpanzees (Kaur et al., 2008; Negrey et al., 2019) and macaques (van den Hoogen et al., 2007).

The zooanthroponosis is very alarming and critical, particularly for the wild Malayan Tiger in Malaysia. The trend of the zooanthroponosis of COVID-19 potentially may push the remaining wild Malayan Tiger population towards extinction. The wild Malayan Tiger has lost approximately $60 \%$ of its population in the last three decades since 1990, as the estimated wild Malayan Tiger population in 2018 was fewer than 200 individuals (DWNP, 2019). The Malayan Tiger population was estimated at about 500 individuals in 1990 (Topani, 1990). As for the captive Malayan Tiger population, there are 69 individuals in ten facilities with

65 individuals in Peninsular Malaysia, three individuals in Sabah and one individual in Sarawak (Ten et al., in preparation). Therefore, there are more or less around 300 individuals of Malayan Tiger in Malaysia. Therefore, this commentary paper is aimed to update the country's existing readiness and preparedness and the immediate response steps in relation to the zooanthroponosis diseases.

\section{Method}

The Department of Wildlife and National Parks (DWNP) had started the zoo audit in the 2011 exercise. The assessment acts as guidance for the DWNP in the issuance of the permit to operate a zoo. The zoo audit assessment has several criteria aiming to provide a minimum standard of care for all the captive populations. The authors have utilised the zoo auditing reports from 2011 to 2016. These reports contain wildlife species and outline the compliance of the zoos and the permanent exhibitions to the Wildlife Conservation (Operation of Zoo) Regulation, 2012 and the Wildlife Conservation (Exhibition) Regulation, 2013. The data for this study was extracted from the report and we make inference on the readiness and preparedness of captive management centres amidst the pandemic COVID-19 disease in Malaysia.

\section{The Wildlife Conservation Centres in Peninsular Malaysia}

In Peninsular Malaysia, there are 11 wildlife conservation centres and two wildlife rescue centres (Table 1) under the jurisdiction of the Malaysian Government (DWNP, 2018a). These centres contain 13 wildlife species which are mostly not susceptible to COVID-19. However, cat species that are susceptible to SARS-CoV-2 are kept at the National Wildlife Rescue Centre Sungkai. The function of both the National Wildlife Rescue Centres Sungkai and Wildlife Rescue Centre Sungai Tengi is to accommodate confiscated and rescued wildlife species. These animals are temporarily placed in the centres and will be released to the wild after treatment, for instance, the Asian palm civets, leopard cat and dusky leaf monkey (DWNP, 2018a). 
Table 1: The wildlife conservation centres and wildlife rescue centres in Peninsular Malaysia

\begin{tabular}{|c|c|c|c|}
\hline No & \multicolumn{2}{|l|}{ Centres } & Wildlife Species \\
\hline 1. & $\begin{array}{l}\text { Wildlife Conservation } \\
\text { Jenderak Selatan, Pahang }\end{array}$ & Centre & Malayan Gaur (Bos gaurus) \\
\hline 2. & $\begin{array}{l}\text { Wildlife Conservation Cent } \\
\text { Musang, Kelantan }\end{array}$ & tre Gua & Sambar Deer (Rusa unicolor) \\
\hline 3. & $\begin{array}{l}\text { Wildlife Conservation } \\
\text { Sungkai, Perak }\end{array}$ & Centre & $\begin{array}{l}\text { Malayan Gaur (Bos gaurus), Sambar Deer (Rusa unicolor), } \\
\text { Mountain Peacock Pheasant (Polyplectron inopinatum), Great } \\
\text { Argus (Argusianus argus), Malaysian Peacock Pheasant } \\
\text { (Polypectron malacense) }\end{array}$ \\
\hline 4. & $\begin{array}{l}\text { Wildlife Conservation } \\
\text { Bangas, Johor }\end{array}$ & Centre & Barking Deer (Muntiacus muntjak) \\
\hline 5. & $\begin{array}{l}\text { Wildlife Conservation } \\
\text { Bukit Marak, Terengganu }\end{array}$ & Centre & Green Peafowl (Pavo muticus) \\
\hline 6. & $\begin{array}{l}\text { Wildlife Conservation } \\
\text { Sungai Dusun, Selangor }\end{array}$ & Centre & Malayan Tapir (Tapirus indicus) \\
\hline 7. & $\begin{array}{l}\text { Wildlife Conservation } \\
\text { Jemaluang, Johor }\end{array}$ & Centre & $\begin{array}{l}\text { Malaysian Peacock Pheasant (Polypectron malacense), Great } \\
\text { Argus (Argusianus argus), Green Peafowl (Pavo muticus) }\end{array}$ \\
\hline 8. & $\begin{array}{l}\text { Wildlife Conservation } \\
\text { Sungai Batu Pahat, Perlis }\end{array}$ & Centre & Lesser Mousedeer (Tragulus javanicus) \\
\hline 9. & $\begin{array}{l}\text { Wildlife Conservation Cent } \\
\text { Kanan, Perak }\end{array}$ & tre Bota & River Terrapin (Batagur affinis) \\
\hline 10. & $\begin{array}{l}\text { Wildlife Conservation } \\
\text { Bukit Pinang, Kedah }\end{array}$ & Centre & River Terrapin (Batagur affinis) \\
\hline 11. & $\begin{array}{l}\text { Wildlife Conservation } \\
\text { Bukit Paloh, Terengganu }\end{array}$ & Centre & River Terrapin (Batagur affinis) \\
\hline 12. & $\begin{array}{l}\text { Wildlife Rescue Centre Sur } \\
\text { Tengi, Selangor }\end{array}$ & & Malayan Porcupine (Hystrix brachyura) \\
\hline 13. & $\begin{array}{l}\text { National Wildlife Rescue C } \\
\text { Sungkai, Perak }\end{array}$ & Centre, & $\begin{array}{l}\text { Malayan Tiger (Panthera tigris), Malayan Sun Bear (Helarctos } \\
\text { malayanus) }\end{array}$ \\
\hline
\end{tabular}

Table adapted from DWNP (2018b)

\section{The Commercial Captive Breeding in Peninsular Malaysia}

The Government of Malaysia has issued a total of 17 permits for commercial captive breeding for Landak Raya, Murai Batu dan other birds (Table 2) (DWNP, 2018a). There are no bats, civets and cat species involved in the commercial breeding as per 17 permits issued by the Malaysian Government in Peninsular Malaysia in 2018 (DWNP, 2018b). The species involved in the commercial breeding are Malayan porcupine, White-rumped sharma and other birds (DWNP, 2018b). As according to current reported cases and studies, those species under the Malaysia commercial captive breeding facility are not susceptible to the infection of COVID-19.

Table 2: Commercial captive breeding permit in Peninsular Malaysia

\begin{tabular}{clc}
\hline No & \multicolumn{1}{c}{ Species } & $\begin{array}{c}\text { Number of } \\
\text { Permits }\end{array}$ \\
\hline 1. & $\begin{array}{l}\text { Malayan Porcupine (Hystrix } \\
\text { brachyura) }\end{array}$ & 7 \\
2. & White-rumped Shama & 6 \\
3. & Other birds & 4 \\
\hline
\end{tabular}

Adapted from DWNP (2018b) 


\section{Wildlife Captive Management in Peninsular Malaysia}

In 2018, Peninsular Malaysia had 32 zoos and permanent exhibitions (DWNP, 2018a). These zoos kept a wide variety of wildlife species, and some animal species are vulnerable to SARS-CoV-2 (Table 3). Audit records for the year of 2011-2016 showed that the pangolins (Manis javanica) which are considered as an intermediate animal host for SARS-CoV-2 were not kept in any of zoos in Peninsular Malaysia.

Table 3: The bats, civets, wild cats, animal species under family Mustelidae and wild boar species kept in captive facilities in Peninsular Malaysia in 2016

\begin{tabular}{|c|c|c|c|c|c|c|}
\hline No. & $\begin{array}{c}\text { Zoo or permanent } \\
\text { exhibition }\end{array}$ & $\begin{array}{c}\text { Bats (No } \\
\text { species/ } \\
\text { individual) }\end{array}$ & $\begin{array}{l}\text { Species } \\
\text { under family } \\
\text { Mustelidae } \\
\text { (no species/ } \\
\text { individual) }\end{array}$ & $\begin{array}{l}\text { Civets (No. } \\
\text { species/ } \\
\text { individual) }\end{array}$ & $\begin{array}{c}\text { Wild cat } \\
\text { (No species/ } \\
\text { individual) }\end{array}$ & $\begin{array}{l}\quad \text { Wild } \\
\text { boar (No } \\
\text { species/ } \\
\text { individual) }\end{array}$ \\
\hline 1. & $\begin{array}{l}\text { Underwater World } \\
\text { Langkawi, Kedah }\end{array}$ & 0 & $1 / 1$ & 0 & 0 & 0 \\
\hline 2. & $\begin{array}{l}\text { Langkawi Wildlife } \\
\text { Park, Kedah }\end{array}$ & 0 & $1 / 3$ & $1 / 3$ & 0 & 0 \\
\hline 3. & $\begin{array}{l}\text { Zoo Taiping \& Night } \\
\text { Safari, Perak }\end{array}$ & $2 / 19$ & $2 / 12$ & $5 / 13$ & $9 / 43$ & $2 / 12$ \\
\hline 4. & $\begin{array}{l}\text { Lost World Petting } \\
\text { Zoo, Perak }\end{array}$ & 0 & 0 & $1 / 2$ & $2 / 3$ & 0 \\
\hline 5. & $\begin{array}{l}\text { Bukit Merah Ecopark, } \\
\text { Perak }\end{array}$ & 0 & $1 / 4$ & $1 / 4$ & 0 & 0 \\
\hline 6. & $\begin{array}{l}\text { Zoo Negara Malaysia, } \\
\text { Selangor }\end{array}$ & $1 / 4$ & $2 / 16$ & $3 / 11$ & $9 / 32$ & 0 \\
\hline 7. & $\begin{array}{l}\text { Sunway Lagoon } \\
\text { Wildlife Park, } \\
\text { Selangor }\end{array}$ & 0 & $2 / 3$ & 0 & $3 / 6$ & 0 \\
\hline 8. & $\begin{array}{l}\text { Farm in The City, } \\
\text { Selangor }\end{array}$ & 0 & $1 / 1$ & 0 & $1 / 1$ & 0 \\
\hline 9. & $\begin{array}{l}\text { Aquaria KLCC, Kuala } \\
\text { Lumpur }\end{array}$ & 0 & $1 / 4$ & 0 & 0 & 0 \\
\hline 10. & Zoo Melaka, Melaka & $1 / 1$ & $1 / 4$ & $3 / 9$ & $5 / 17$ & 0 \\
\hline 11. & $\begin{array}{l}\text { A'Famosa Safari } \\
\text { Wonderland, Melaka }\end{array}$ & 0 & $1 / 2$ & $3 / 10$ & $3 / 30$ & 0 \\
\hline 12. & $\begin{array}{l}\text { Zoo Negeri Johor, } \\
\text { Johor }\end{array}$ & 0 & $1 / 9$ & $3 / 4$ & $3 / 18$ & 0 \\
\hline 13. & $\begin{array}{l}\text { Taman Teruntum, } \\
\text { Pahang }\end{array}$ & 0 & $1 / 8$ & $1 / 3$ & $1 / 1$ & 0 \\
\hline 14. & $\begin{array}{l}\text { Bukit Gambang Safari } \\
\text { World, Pahang }\end{array}$ & 0 & $1 / 2$ & $3 / 9$ & $10 / 35$ & 0 \\
\hline 15. & $\begin{array}{l}\text { Zoo Kemaman, } \\
\text { Terengganu }\end{array}$ & 0 & 0 & $1 / 1$ & $2 / 6$ & 0 \\
\hline
\end{tabular}

Sources: Data were obtained from the unpublished zoos audit reports 2016, DWNP

Under the Wildlife Conservation Act 2010, there is a prerequisite to operate a zoo, where Clause 28(b) requires the zoo operator to prepare an emergency plan, relating to plague, natural disaster and animal escape in order for the zoos to be given a permit to operate. All zoos in Peninsular Malaysia have obtained the permit to operate a zoo. Thus, it can beassumed 
that the zoo has the contingency plan in place on the zoonotic disease prevention measures. The first author has also examined the zoo reports and summarised the selected disease preventive measures of the zoos in 2016. The selected preventive measures concerning the control of the diseases are shown in Table 4.

Table 4: The preventive measures for selected zoos that kept species susceptible to COVID-19 as in 2016

\begin{tabular}{|c|c|c|c|c|c|c|c|}
\hline No. & Captive Facility & $\begin{array}{c}\text { Contingency/ } \\
\text { Emergency } \\
\text { plan }\end{array}$ & $\begin{array}{c}\text { Employment } \\
\text { veterinarian/ } \\
\text { consultant } \\
\text { veterinarian }\end{array}$ & $\begin{array}{c}\text { Minimum } \\
\text { biosafety } \\
\text { measure } \\
\text { (foot bath) }\end{array}$ & $\begin{array}{c}\text { Animal } \\
\text { health care } \\
\text { assessment } \\
\text { record }\end{array}$ & $\begin{array}{c}\text { Preparation } \\
\text { of } \\
\text { quarantine } \\
\text { area }\end{array}$ & $\begin{array}{c}\text { Wildlife } \\
\text { Performance }\end{array}$ \\
\hline 1. & $\begin{array}{l}\text { Underwater World } \\
\text { Langkawi, Kedah }\end{array}$ & 1 & 1 & 1 & 1 & 1 & 0 \\
\hline 2. & $\begin{array}{l}\text { Langkawi Wildlife } \\
\text { Park, Kedah }\end{array}$ & 1 & 1 & 1 & 1 & 1 & 0 \\
\hline 3. & $\begin{array}{l}\text { Zoo Taiping \& } \\
\text { Night Safari, } \\
\text { Perak }\end{array}$ & 1 & 1 & 1 & 1 & 1 & 0 \\
\hline 4. & $\begin{array}{l}\text { Lost World Petting } \\
\text { Zoo, Perak }\end{array}$ & 1 & 1 & 1 & 1 & 1 & 1 \\
\hline 5. & $\begin{array}{l}\text { Bukit Merah } \\
\text { Ecopark, Perak }\end{array}$ & 1 & 1 & 0 & 1 & 1 & 0 \\
\hline 6. & $\begin{array}{l}\text { Zoo Negara } \\
\text { Malaysia, } \\
\text { Selangor }\end{array}$ & 1 & 1 & 1 & 1 & 1 & 1 \\
\hline 7. & $\begin{array}{l}\text { Sunway Lagoon } \\
\text { Wildlife Park, } \\
\text { Selangor }\end{array}$ & 1 & 1 & 1 & 1 & 1 & 1 \\
\hline 8. & $\begin{array}{l}\text { Farm In The City, } \\
\text { Selangor }\end{array}$ & 1 & 1 & 1 & 1 & 1 & 0 \\
\hline 9. & $\begin{array}{l}\text { Aquaria KLCC, } \\
\text { Kuala Lumpur }\end{array}$ & 1 & 1 & 1 & 1 & 1 & 0 \\
\hline 10. & $\begin{array}{l}\text { Zoo Melaka, } \\
\text { Melaka }\end{array}$ & 1 & 1 & 1 & 1 & 1 & 1 \\
\hline 11. & $\begin{array}{l}\text { A'Famosa Safari } \\
\text { Wonderland, } \\
\text { Melaka }\end{array}$ & 1 & 1 & 1 & 1 & 1 & 1 \\
\hline 12. & Zoo Negeri Johor & 1 & 1 & 0 & 0 & 1 & 0 \\
\hline 13. & $\begin{array}{l}\text { Taman Teruntum, } \\
\text { Pahang }\end{array}$ & 0 & 1 & 1 & 0 & 1 & 0 \\
\hline 14. & $\begin{array}{l}\text { Bukit Gambang } \\
\text { Safari World, } \\
\text { Pahang }\end{array}$ & 1 & 1 & 1 & 1 & 1 & 1 \\
\hline 15. & $\begin{array}{l}\text { Zoo Kemaman, } \\
\text { Terengganu }\end{array}$ & 1 & 1 & 1 & 1 & 1 & 0 \\
\hline
\end{tabular}

Notes:

1 Preventive measures existed

0 No preventive measure 


\section{Future planning in preventive measures}

We proposed seven measures to be implemented either by reviewing the existing measures or formulating new actions by the government. Those disease-control preventive measures are:

1. The Malaysian Government, through DWNP, must construct two important framework documents as part of the zoo contingency plan. First, the zoo contingency management strategy which consists of four phases: mitigation, preparedness, response and recovery. Second is the implementable zoo contingency action plan consisting of emergency scenarios, physical training, hands-on drills, continuous learning, efficient use of technology, seamless coordination, and communication for smooth execution during an emergency. The authors have noted that the Giant Panda husbandry management is probably the model of endangered species captive management and the study published by Ten et al. (2020) has indicated that the Giant Panda husbandry management is duplicable with adaptation. Under Clause 28(b), Wildlife Conservation Act 2010, all zoos must draft a contingency plan in place of the potential outbreak of zoonotic diseases. With the zooanthroponosis situation, the zoo operators will need to amend the existing plan by putting in measures to protect the animals under their care.

2. DWNP has established a Molecular Zoonotic Unit to monitor and conduct research related to wildlife zoonotic disease. In 2018, it was reported that this unit had screened zoonotic disease in bats, mammals and non-human primate (DWNP, 2018a). The continuation of the zoonotic disease surveillance programme is important.

3. The Malaysian Association for Zoological Parks and Aquaria (MAZPA) is a platform for the Malaysian zoo community with the aims to develop closer interaction, cooperation and understanding among the members towards wildlife conservation and education. In response to the COVID-19 pandemic outbreak in Malaysia, MAZPA has drafted Guidelines \& Good Practices for prevention of COVID-19 infection in zoos, and this guideline needs to be revised based on the latest disease control development. This document outlined basic preventive steps under three sections, 1) basic protective measures against the virus, 2) basic safety measures at the zoo area and 3) zoo staff and all personnel working with animals.

4. As for the commercial captive breeding, the Malaysian Government will need to relook into the commercial captive breeding policy and the standard procedure in issuing the permit. For wild animals that have been identified for commercialisation, a throughout screening and study on potential zoonotic diseases are needed. On top of the stringent permit approval requirement, the authority should conduct an annual facility audit and review all relevant procedures to stop any potential disease outbreak chain.

5. Peninsular Malaysia is home to the Malayan Tiger. The lack of herd immunity against diseases will probably lead to spillover event to animals in zoos and the wild population in the natural forest (Abdullah et al., 2020). All the captive-bred Malayan Tigers are the potential stock for species release programme. Disease screening which includes for SARS-CoV-2 needs to be included in the pre-release protocol. Before any knowledge is available on the impact of the SARS-CoV-2 virus on the Malayan Tiger wild population, the authority will need to draw up a new policy which underlines that any captive-bred Malayan Tiger infected with the SARS$\mathrm{CoV}-2$ would exclude that animal group from the release programme.

6. The COVID-19 susceptible animal species in captivity must be further protected by discontinuing or limiting the wildlife performance and human-wildlife interactive activities. These visitor-animal interactions could possibly lead to the transmission of 
SARS-CoV-2 to animals in captivity. There is a possibility of transmission of SARSCoV-2 to animals in captivity. The authority must revisit the Wildlife Interactive Programme Management guideline (DWNP, 2014), the Wildlife Mobile Exhibition Handling guideline (DWNP, 2017a) and the Wildlife Rearing guideline (DWNP, 2011) to safeguard the welfare of those COVID-19 susceptible animals.

7. Zoo tourism is hit badly by the outbreak of the COVID-19 pandemic. The Malaysian Government has imposed the Movement Control Order, starting 18 Mac 2020 until 9 June 2020. The Movement Control Order has closed the zoos and permanent exhibitions in the country as a measure to control the spread of the diseases. Until the date of this write-up, the Movement Control Order was still enforced and may be extended further. The closing down of zoos resulted in the loss of income from gate collection, which then has affected the animal daily welfare maintenance, including the medicine and food supply. Clause 14(1) of the Wildlife Conservation (Operation of Zoo) Regulation, 2012 has enabled the authority to collect a sum of money to finance any cost incurred by the Government in seizing, keeping and maintaining the seized animals. The authority is recommended to visit this clause in preparation to handle similar contingency issues. The MAZPA is foreseen as the potential strong player in managing this emergency fund so that the zoos can be financially sustainable to overcome future pandemic or contingency issues.

\section{Conclusion}

The authority has laid groundwork in terms of policy, law and guidelines in the zoonotic disease control management. The COVID-19 is a new pandemic, and the country has been caught by surprise with its speed and method of transmission. Although there are no concrete pieces of evidence that the animal from family
Mustelidae (e.g., ferrets), cats and civets can be infected by the SARS-CoV-2, the virus has caused COVID-19 in Malayan Tiger kept overseas. Thus, we recommend that the authority to consider the preventive measures above by either formulating a new policy or revisit the guidelines in order to be more prepared in responding to future pandemic zoonosis.

\section{Acknowledgements}

We thank the Ministry of Energy and Natural Resources (KeTSA) Malaysia for the permission and support. We also thank the Director- General Dato' Abdul Kadir Bin Abu Hashim, Department of Wildlife and National Parks (DWNP) Peninsular Malaysia for research permit and invaluable assistance from various DWNP officers. This data collection permission was granted by DWNP and funded by KeTSA through Giant Panda Research Consortium Malaysia (KPGPM/UMT/53161) lead by Professor Dr. Mohd Tajuddin Abdullah.

\section{References}

Abdullah, M. T., Edinur, H. A., \& Ten, D. C. Y. (2020, April 2020). COVID-19 and the emergence of zooanthroponosis. Academic Affairs Quick Update, 50, 1-2.

Daly, N. (2020). Trafficked pangolins can carry coronaviruses closely related to pandemic strain. National Geographic.

DWNP. (2011). Garis Panduan Pemeliharaan Hidupan Liar. Kuala Lumpur: Department of Wildlife and National Parks Retrieved from https://www.wildlife.gov.my/images/ document/penerbitan/GARISPANDUAN/ PEMELIHARAAN\%20HIDUPAN\%20

LIAR/GARIS $\% 20$ PANDUAN $\% 20$ PEMELIHARAAN\%20HIDUPAN\%20

LIAR.pdf. Accessed on 3 May 2020.

DWNP. (2014). Garis Panduan Pengurusan Program Interaktif Hidupan Liar. Retrieved from https://www.wildlife.gov.my/images/ document/penerbitan/GARISPANDUAN/ 


\section{GARIS_PANDUAN_INTERAKTIF_ HIDUPAN_LIAR.pdf}

DWNP. (2017a). Garis Panduan Pengendalian Pameran Bergerak Hidupan Liar. Retrieved from https://www.wildlife.gov.my/ images/GARIS_PANDUAN_PERMIT_ BERGERAK_HIDUPAN_LIAR.pdf

DWNP. (2017b). Red List of Mammals for Peninsular Malaysia Version 2.0. Kuala Lumpur: Department of Wildlife and National Parks.

DWNP. (2018a). 2018 Annual Report. Cheras, Kuala Lumpur: Department of Wildlife and National Parks Retrieved from https:// www.wildlife.gov.my/images/document/ penerbitan/laporantahunan/LT2018.pdf.

DWNP. (2018b). 2018 Annual Report. Cheras: Department of Wildlife and National Parks.

DWNP. (2019). Harimau Malaya. Retrieved from https://harimau.my/.

Guan, Y., Zheng, B. J., He, Y. Q., Liu, X. L., Zhuang, Z. X., Cheung, C. L., Luo, S. W., Li, P. H., Zhang, L. J., Guan, Y. J., Butt, K. M., Wong, K. L., Chan, K. W., Lim, W., Shortridge, K. F., Yuen, K. Y., Peiris, J. S. M., \& Poon, L. L. M. (2003). Isolation and characterization of viruses related to the SARS Coronavirus from animals in Southern China. Science, 302(5643), 276278. doi:10.1126/science. 1087139

Ji, W., Wang, W., Zhao, X., Zai, J., \& Li, X. (2020). Cross-species transmission of the newly identified coronavirus 2019-nCoV. Journal of Medical Virology, 92(4), 433440. doi:10.1002/jmv.25682

Kaur, T., Singh, J., Tong, S., Humphrey, C., Clevenger, D., Tan, W., Szekely, B., Wang, Y., Li, Y., Alex Muse, E., Kiyono, M., Hanamura, S., Inoue, E., Nakamura, M., Huffman, M. A., Jiang, B., \& Nishida, T. (2008). Descriptive epidemiology of fatal respiratory outbreaks and detection of a human-related metapneumovirus in wild chimpanzees (Pan troglodytes) at Mahale Mountains National Park, Western Tanzania.
American Journal of Primatology, 70(8), 755-765. doi:10.1002/ajp.20565

Lam, T. T.-Y., Shum, M. H.-H., Zhu, H.-C., Tong, Y.-G., Ni, X.-B., Liao, Y.-S., Wei, W., Cheung, W. Y.-M., Li, W.-J., Li, L.-F., Leung, G. M., Holmes, E. C., Hu, Y.-L., \& Guan, Y. (2020). Identifying SARS-CoV-2 related coronaviruses in Malayan pangolins. Nature. doi:10.1038/s41586-020-2169-0

Liu, P., Chen, W., \& Chen, J. P. (2019). Viral metagenomics revealed Sendai Virus and Coronavirus infection of Malayan Pangolins (Manis javanica). Viruses, 11(11), 979. doi:http://dx.doi.org/10.3390/v11110979

McGreevy, N. (2020). A Tiger in the Bronx Zoo tested positive for COVID-19. Smithsonian Magazine.

Negrey, J. D., Reddy, R. B., Scully, E. J., PhillipsGarcia, S., Owens, L. A., Langergraber, K. E., Mitani, J. C., Emery Thompson, M., Wrangham, R. W., Muller, M. N., Otali, E., Machanda, Z., Hyeroba, D., Grindle, K. A., Pappas, T. E., Palmenberg, A. C., Gern, J. E., \& Goldberg, T. L. (2019). Simultaneous outbreaks of respiratory disease in wild chimpanzees caused by distinct viruses of human origin. Emerging Microbes \& Infections, 8(1), 139-149. doi:10.1080/222 21751.2018.1563456

OIE. (2020). Questions and answers on the 2019 Coronavirus disease (COVID-19). Retrieved from https://www.oie.int/en/ scientific-expertise/specific-informationand-recommendations/questions-andanswers-on-2019novel-coronavirus/

Owen, M. S., Karen, A. T., Yange, Z., Dean, D. E., Eileen, S., Jane, K., Steven, M. W., Kevin, J. K., Jennifer, K., Michael, J. K., \& Kathryn, C. G. (2014). Human metapneumovirus infection in Chimpanzees, United States. Emerging Infectious Disease journal, 20(12), 2115. doi:10.3201/eid2012.140408

Salyer, S. J., Silver, R., Simone, K., \& Barton Behravesh, C. (2017). Prioritizing zoonoses for global health capacity building-Themes 
from one health zoonotic disease workshops in 7 countries, 2014-2016. Emerging infectious diseases, 23(13), S55-S64. doi:10.3201/eid2313.170418

Shi, J., Wen, Z., Zhong, G., Yang, H., Wang, C., Huang, B., Liu, R., He, X., Shuai, L., Sun, Z., Zhao, Y., Liu, P., Liang, L., Cui, P., Wang, J., Zhang, X., Guan, Y., Tan, W., Wu, G., Chen, H., \& Bu, Z. (2020). Susceptibility of ferrets, cats, dogs, and other domesticated animals to SARScoronavirus 2. Science, 368(6494), 10161020. doi:10.1126/science.abb7015

Ten, D. C. Y., Jani, R., Azizi, R., Ramli, M. N., Yang, H., Zainudin, A. N., Samsuddin, A. H., Hashim, N. H., Afiq, R. M. N., Zahidin, M. A., Mohd Raffi, M. A., Lola, M. S., \& Abdullah, M. T. (2020). Data on diet and growth by Giant Panda in Zoo Negara, Malaysia. Data in Brief, 105082. doi:https:// doi.org/10.1016/j.dib.2019.105082

Ten, D. C. Y.,Jani, R., Hashim, N. H., Ellaguipilly, S. T., \& Abdullah, M. T. (in preparation). The readiness of Malaysia incorporating in situ and ex situ conservation to save Malayan Tiger in the wild.

Topani, R. (1990). Status and distribution of tiger (Panthera tigris corbetti). Journal of Wildlife and Parks, 9, 71-102.

van den Hoogen, B. G., Herfst, S., de Graaf, M., Sprong, L., van Lavieren, R., van Amerongen, G., Yüksel, S., Fouchier, R. A. M., Osterhaus, A. D. M. E., \& de Swart,
R. L. (2007). Experimental infection of macaques with human metapneumovirus induces transient protective immunity. Journal of General Virology, 88(4), 12511259. doi:https://doi.org/10.1099/vir.0.826 63-0

WCS. (2020, 22 April 2020). Update: Bronx Zoo Tigers and Lions Recovering from COVID19. WCS Newroom. Retrieved from https://newsroom.wcs.org/News-

Releases/article Type/Article View/ articleId/14084/Update-Bronx-Zoo-Tigersand-Lions-Recovering-from-COVID-19. aspx, Accessed on 26 April 2020

WHO. (2020). Coronavirus disease (COVID-19) Weekly Epidemiological Update. Retrieved from https://www.who.int/docs/ defaultsource/coronaviruse/situationreports/20200914-weekly-epi-update-5. pdf?sfvrsn=cf929d04_2. Accessed on 16 September 2020

Zhou, P., Yang, X.-L., Wang, X.-G., Hu, B., Zhang, L., Zhang, W., Si, H.-R., Zhu, Y., Li, B., Huang, C.-L., Chen, H.-D., Chen, J., Luo, Y., Guo, H., Jiang, R.-D., Liu, M.-Q., Chen, Y., Shen, X.-R., Wang, X., Zheng, X.S., Zhao, K., Chen, Q.-J., Deng, F., Liu, L.L., Yan, B., Zhan, F.-X., Wang, Y.-Y., Xiao, G.-F., \& Shi, Z.-L. (2020). A pneumonia outbreak associated with a new coronavirus of probable bat origin. Nature, 579(7798), 270-273. doi:10.1038/s41586-020-2012-7 